Ковшун Н. Е. [1; ORCID ID: 0000-0003-0573-2932], д.е.н., професор, Мазур Н. 0. [1; ORCID ID: 0000-0001-8673-5873], к.е.н., доцент

'Національний університет водного господарства та природокористування, м. Рівне

\title{
УРАХУВАННЯ МОЛОДІЖНОЇ МІГРАЦІЇ ПРИ ФОРМУВАННІ ПРІОРИТЕТІВ РЕГУЛЮВАННЯ РИНКУ ПРАЦІ УКРАЇНИ
}

Досліджено міграційні процеси в молодіжному сегменті ринку праці України. Розглянуто особливості міграції молоді Рівненської області як регіону з високим рівнем відтоку робочої сили. Наведено результати анкетування студентів 1-3 курсів закладів вищої освіти Рівненщини щодо їх міграційних настроїв. Встановлено рівень зацікавленості молоді у виїзді за кордон 3 метою працевлаштування. Визначено фактори, які стимулюють міграційні процеси. Досліджено вплив рівня зайнятості та заробітної плати на відтік населення України за кордон.

Ключові слова: безробіття; зайнятість; заробітна плата; молодь; міграція; ринок праці; трудова міграція.

На сучасному етапі розвитку нашої держави, ускладненому економічною та політичною кризами, актуальною $є$ оптимізація основних параметрів національного ринку праці. Серед пріоритетів регулювання ринку праці - підвищення економічної активності працездатного населення, підтримка соціально вразливих груп населення, скорочення вимушеної неповної зайнятості, підвищення якості трудового потенціалу та мотивування до продуктивної діяльності. Особливої уваги потребує урахування потреб молодіжного сегменту, що зумовлено еміграцією з України освіченої, кваліфікованої молоді. Існує нагальна необхідність оцінки міграційних настроїв молоді, рівня їі інтеграції в соціальноекономічний простір держави та світу, прогнозування основних параметрів ринку праці й розробки на цій основі стратегічних напрямів розвитку його молодіжного сегменту.

Теоретичні та прикладні проблеми розвитку національного ринку праці розглянуто в працях С.Бандура [1], О. Грішнової [2], А. Колота [3], О. Лисюк [4], Е. Лібанової [5], Л. Лісогор [6], І. Юрчик [7] та інших. Питанням міграції присвячені дослідження багатьох вітчизняних і зарубіжних вчених. Значна увага, особливо в працях українських дослідників, приділяється зовнішній міграції. При цьому 
основним завданням досліджень $€$ виявлення ії впливу на соціальноекономічний розвиток країни. Активізація міграційних процесів населення України потребує постійного різностороннього моніторингу з метою виявлення пріоритетів регулювання ринку праці. Переважну частку емігрантів з України нині складає молодь, тому міграційні процеси в Україні $\epsilon$ надзвичайно важливою проблемою сьогодення. При цьому найбільший відтік населення за кордон відбувається із західних регіонів держави. Це зумовлює необхідність постійного моніторингу міграційних намірів студентської молоді та виявлення рівня схильності до еміграції, а також причин та чинників, які формують міграційні настрої.

Метою статті $€$ аналіз міграційних настроїв молоді Рівненщини, що дозволить сформувати рекомендації щодо формування пріоритетів регулювання національного ринку праці.

Суть міграції, її причини, наслідки та можливості регулювання вивчаються різними науковими школами. Так, неокласики причину трудової міграції вбачали у географічних відмінностях у попиті та пропозиції робочої сили, тобто на територіях з надлишком робочої сили спостерігається низька заробітна плата, а в регіонах, для яких характерний ї̈ дефіцит, - висока. Тобто, розмір заробітної плати визнається основним чинником рішення мігрантів. Відповідно до теорії глобальних систем, міграція $€$ результатом глобалізації, що передбачає підвищення трудової мобільності населення, його здатності мігрувати у пошуках кращих умов життя. Науковці, які вивчають проблеми ринку праці в Україні, виділяють п'ять груп факторів міграції: економічні, політичні, соціальні, культурні та екологічні. Саме вони призвели до того, що наша держава увійшла до п'ятірки країн із найвищим рівнем еміграції населення.

Вплив цих факторів на різних сегментах ринку праці, проте, проявляється з різною силою. Окремої уваги потребує дослідження міграційних настроїв студентської молоді. Вивчення молодіжної міграції здійснюється як для рівня країни в цілому [8; 9], так і для окремих регіонів [10].

Зазначимо, що станом на 2018 рік $21 \%$ української молоді віком 14-34 роки виявили бажання якийсь час попрацювати за кордоном, але потім повернутися в Україну, проте лише 11,7\% здійснюють пошук реальної можливості міграції [11]. Результати опитування залежать від соціального статусу, віку, статі, місця проживання представників цільової групи.

Рівненщина - регіон 3 великим відтоком населення як на заробітки, так і на навчання не лише в інші області України, а й за кордон. В області функціонує 12 закладів вищої освіти, з них 5 - 
університети, академії та інститути. У 2019 році на території Рівненської області навчалось понад 30 тис. здобувачів вищої освіти. Тому вивчення міграційних настроїв у даному сегменті є достатнім підґрунтям для визначення пріоритетів реформування ринку праці в Україні.

3 цією метою розроблено анкету у вигляді google-форми, яка містить питання, що дозволяють виявити основні потреби респондентів, характер міграційних настроїв та їх причини. Запрошення до опитування було надіслано студентам 1-3 курсів денної форми навчання Національного університету водного господарства та природокористування, Рівненського державного гуманітарного університету, Національного університету «Острозька академія», Приватного вищого навчального закладу «Міжнародний економіко-гуманітарний університет імені академіка Степана Дем'янчука». В цілому відгукнулось $12 \%$ потенційних респондентів. Найбільш активними виявились здобувачі вищої освіти Національного університету водного господарства та природокористування (38\% опитаних).

Початкові питання анкети зорієнтовані на виявлення вже існуючого у студентів досвіду поїздок в інші країни. Значна частка опитаних здобувачів вищої освіти мають уявлення про рівень життя в економічно розвинених країнах на основі власного досвіду перебування за кордоном (рис. 1).

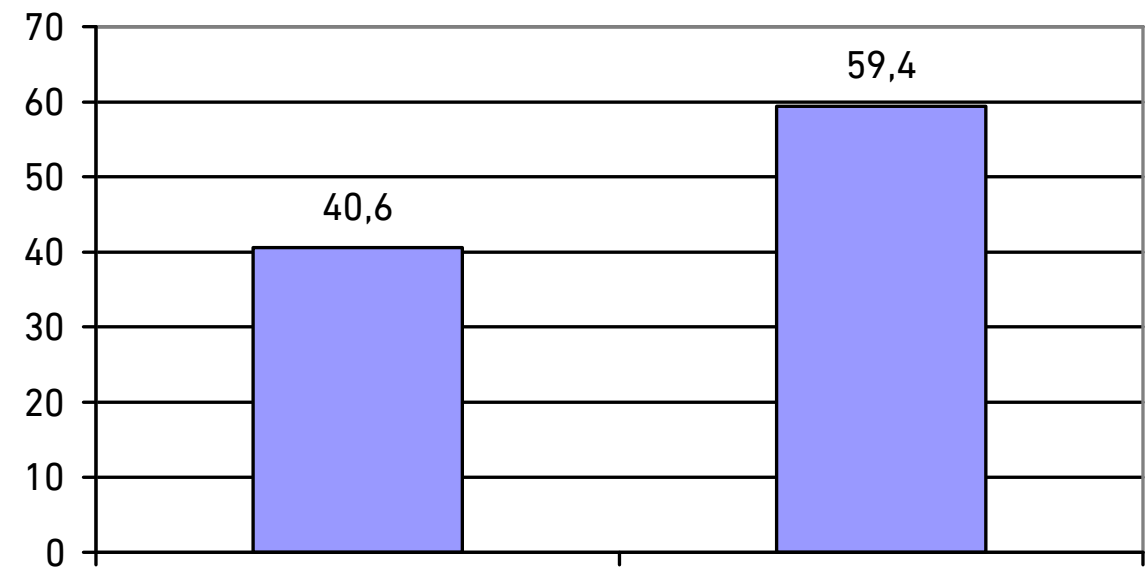

так

Hi

Рис. 1. Наявність у студентської молоді Рівненщини досвіду перебування за кордоном, \%

Серед причин закордонних поїздок переважають подорожі $61 \%$ та відпочинок - 54\% відповідей. Разом з тим, 22\% респондентів 
зазначили, що перебували за кордоном з метою заробити гроші. Це викликає певну пересторогу, оскільки свідчить про суттєве зниження віку трудових мігрантів та гостроту проблеми неможливості отримати бажаний рівень доходів старшими членами їхніх сімей. В цілому в Україні, згідно з соціологічними опитуваннями [11], питома вага громадян віком від 14 до 34 років, які впродовж 2018 року виїздили за кордон з метою тимчасових заробітків, становить лише 5,2\% опитаних, а упродовж останніх п'яти років $3,1 \%$. На противагу 91,3\% тих, які ніколи не виїздили за кордон 3 метою тимчасового працевлаштування, серед студентів Рівненської області таких виявилось менше $80 \%$.

Студентство $€$ основним інтелектуальним потенціалом держави. Тому в анкеті передбачено питання щодо настроїв респондентів стосовно місця проживання після здобуття вищої освіти: в Україні чи за іï межами. Результати дослідження засвідчили, що $66 \%$ респондентів не впевнені, чи виїжджати за кордон, чи жити далі на батьківщині, $22 \%$ опитаних визначилися, що вони однозначно залишатимуться жити в Україні, а 12\% студентів зорієнтовані на виїзд за кордон.

На сьогодні загальновизнано, що відтік працездатного населення 3 України спричиняють переважно такі фактори, як низька заробітна плата, нестабільність економічної ситуації, незабезпеченість населення робочими місцями, політична нестабільність та напруженість в державі, зневіра щодо можливості влаштувати власне майбутнє і майбутнє дітей в своїй країні, відсутність можливості реалізувати свій потенціал, що збільшує відтік інтелектуальної та висококваліфікованої частини працездатного населення [12]. Ці чинники характеризують трудову міграцію як основний засіб забезпечення прийнятного рівня життя значної частини населення країни.

Причинами міграційних настроїв молоді Рівненщини $\epsilon$ переважно економічні чинники. Студенти прагнуть виїхати з України через відсутність належних умов для працевлаштування (49\%), неможливість забезпечити собі гідний рівень матеріального добробуту (52\%), високий рівень корупції (47\%), та найчастіше через відсутність робочого місця, яке б відповідало особистим вимогам молодої людини (76\%). Менш актуальними є бажання оволодіти новими знаннями та навичками (31\%) або небажання залишатись в Україні з причин соціального характеру (27\%). В результаті аналізу відповідей респондентів у розрізі їхніх групувань за соціально-демографічними ознаками не виявлено суттєвих відмінностей у відповідях за статтю або за місцем проживання до 
вступу в університет.

Порівняльний аналіз статистичних даних в розрізі регіонів України також підтверджує найвищу залежність відтоку населення 3 територій певних територіально-адміністративних одиниць саме від рівня зайнятості населення (рис. 2) та рівня його доходів.

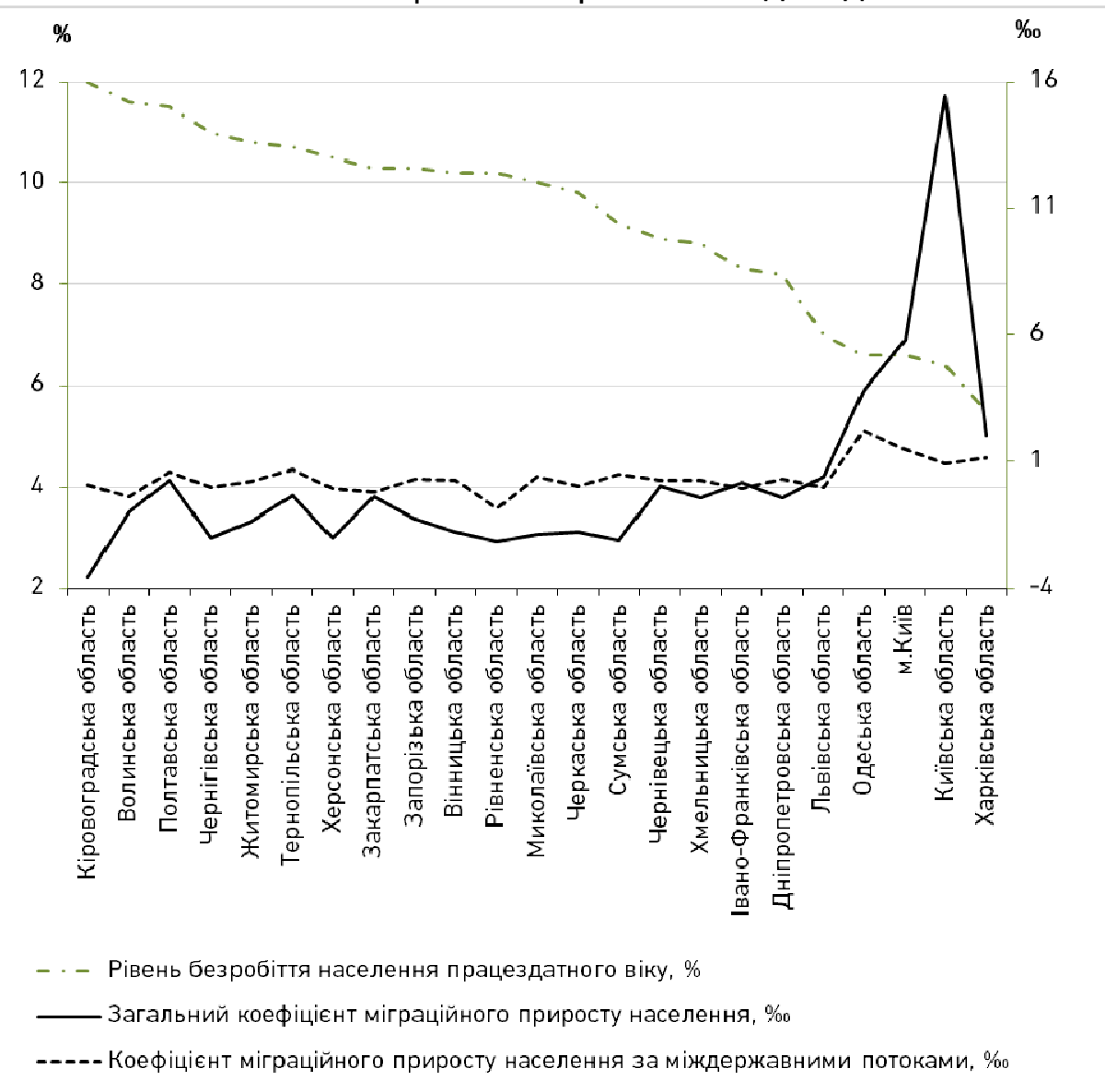

Рис. 2. Взаємозв'язок показників міграції та рівня безробіття населення у працездатному віці (ранжовано за рівнем безробіття)

Джерело: побудовано авторами на основі [13; 14]

Коефіцієнт кореляції між міграційним приростом та рівнем безробіття населення працездатного віку становить -0,61 для міждержавних потоків і -0,67 для загального показника. Дещо слабший зв'язок між рівнем безробіття економічно активного населення (EAH) і міграцією пояснюється недосконалістю вітчизняних методик визначення чисельності економічно активного населення. За своєю суттю цей показник повинен більш точно відображати досліджувану залежність, тому що саме ця категорія населення включає осіб, які не лише можуть, а й бажають працювати (табл. 1). 
Кореляційна залежність міграційних потоків від показників зайнятості населення в регіоні

\begin{tabular}{|c|c|c|c|c|c|}
\hline Коефіцієнт кореляції & 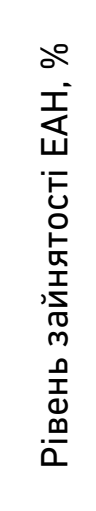 & 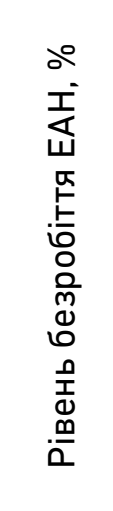 & 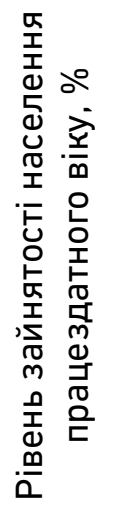 & 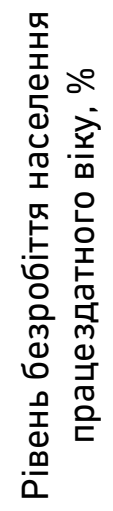 & 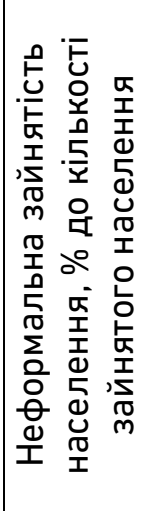 \\
\hline $\begin{array}{l}\text { Загальний коефіцієнт } \\
\text { міграційного приросту населення } \\
\text { (за всіма потоками), \%о }\end{array}$ & 0,34 & $-0,48$ & 0,27 & $-0,67$ & $-0,42$ \\
\hline $\begin{array}{l}\text { Коефіцієнт міграційного приросту } \\
\text { населення за міждержавними } \\
\text { потоками, \%о }\end{array}$ & 0,46 & $-0,42$ & 0,46 & $-0,61$ & $-0,49$ \\
\hline
\end{tabular}

Джерело: розраховано авторами на основі [13; 14]

Натомість тіснота зв'язку показників рівня зайнятості та міграції $\epsilon$ значно слабшою. Причиною цього може бути значна частка прихованого безробіття, вираженого зокрема у формі часткового безробіття. Варто зауважити, що в даному випадку неформальна зайнятість $€$ чинником, який стримує громадян від міграції, надаючи їм джерело доходів, а отже й забезпечення певного рівня та якості життя.

Основним фактором міграції в теорії сегментованого ринку визнані структурні потреби економік розвинених держав. Зокрема, економічно розвинені країни мають первинний ринок із кваліфікованою і високооплачуваною працею та вторинний ринок із некваліфікованою низькооплачуваною працею, яка $\epsilon$ непривабливою для місцевих жителів. Тому в таких країнах для заповнення робочих місць на вторинному ринку праці потрібен приплив іммігрантів.

Однією з основних рис сучасної української еміграції є виїзд висококваліфікованих працівників, які згодом втрачають свої професійні навики, оскільки за кордоном виконувана ними робота часто має примітивний та непрестижний характер. На сьогодні 
основними сферами, в яких зайняті працівники-мігранти, є: будівництво, сільське господарство (збирання врожаю), домашнє господарство (прибирання домівки, готування їжі, доглядання дітей та немічних людей похилого віку), сфера торгівлі та сервісу [15].

Показником, який найточніше характеризує залежність механічного руху від рівня життя населення у межах регулювання ринку праці, є середня заробітна плата (табл. 2).

Таблиця 2

Кореляційна залежність міграційних потоків від розміру заробітної плати в регіоні

\begin{tabular}{|c|c|c|c|}
\hline Коефіцієнт кореляції & $\begin{array}{l}\text { Середньо- } \\
\text { місячна } \\
\text { заробітна } \\
\text { плата, грн }\end{array}$ & $\begin{array}{c}\text { Середня } \\
\text { заробітна } \\
\text { плата за } \\
\text { відпра- } \\
\text { цьовану } \\
\text { годину, грн }\end{array}$ & $\begin{array}{c}\text { Середньомісячна } \\
\text { заробітна плата } \\
\text { штатних } \\
\text { працівників, оплата } \\
\text { яких фінансується } \\
\text { за рахунок } \\
\text { бюджетних коштів, } \\
\text { грн }\end{array}$ \\
\hline $\begin{array}{l}\text { Загальний коефіцієнт } \\
\text { міграційного приросту } \\
\text { населення (за всіма } \\
\text { потоками), \%о }\end{array}$ & 0,51 & 0,50 & 0,45 \\
\hline $\begin{array}{l}\text { Коефіцієнт } \\
\text { міграційного приросту } \\
\text { населення за } \\
\text { міждержавними } \\
\text { потоками, \%о }\end{array}$ & 0,46 & 0,40 & 0,45 \\
\hline
\end{tabular}

Джерело: розраховано авторами на основі $[14 ; 16]$

Заробітки емігрантів є, як мінімум, у три рази вищими, ніж в Україні [15].

Оскільки для прийняття такого важливого рішення, як переїзд в іншу місцевість, а тим паче еміграція з метою отримання джерел забезпечення певного рівня життя, приймається більшістю людей не миттєво, а з певним часовим лагом від моменту втрати джерела доходів або суттєвого зменшення їх величини, в розрахунках кореляційних коефіцієнтів використано дані про механічний рух населення за 2019 рік, а ті, що можуть характеризувати зайнятість та доходи найманих працівників, - за попередній аналогічний період. Для достовірності співставлення показників з розрахунків вилучено дані, які характеризують соціально-економічне становище у Донецькій та Луганській областях, оскільки характер міграції населення регіонів, територія яких частково окупована, дещо 
Серія «Економічні науки»

Випуск 4(92) 2020 p.

відрізняється від інших.

Згідно з результатами опитування, за межі країни з метою навчання, тимчасового працевлаштування або подальшого проживання прагнуть виїхати 87\% здобувачів вищої освіти Рівненщини. Основними стримуючими чинниками для постійної еміграції студентів $€$ залежність від думки родичів та друзів, наявність роботи та матеріальний добробут, зокрема, забезпеченість власним житлом.

Попри такі загальновизнані позитивні наслідки для України міграції її населення, як сприяння інтеграції держави у міжнародний ринок праці та ринок освітніх послуг, зменшення напруги на ринку праці внаслідок зниження реального рівня безробіття, надходження зароблених мігрантами коштів у національну економіку, значною загрозою молодіжної еміграції для соціальної безпеки нашої держави $€$ втрата свого трудового, зокрема інтелектуального потенціалу. При цьому, необхідно враховувати, що таке позитивне явище, як освітня міграція сьогодні досить часто $\epsilon$ формою потенційної трудової імміграції. Тому першочерговим пріоритетом регулювання вітчизняного ринку праці, що сприятиме утриманню та поверненню освіченої, кваліфікованої молоді в Україну, безкомпромісно є створення нових ефективних робочих місць у високопродуктивних, конкурентоспроможних секторах національної економіки. Взаємопов'язаною і нагальною потребою є узгодження пропозицій вітчизняного ринку освітніх послуг з потребами ринку праці як щодо переліку певних професій та кількості випускників, так і щодо змістовного наповнення конкретних освітніх програм відповідно до запитів роботодавців. Щодо останнього, то орієнтація закладів освіти на вимоги і очікування не лише вітчизняних, а й закордонних роботодавців, дозволить молодим працівникам не втрачати професійні знання під час тимчасової трудової міграції, а, навпаки, примножувати їх і тим самим підвищувати інтелектуальний потенціал України. Дотичними прерогативами регулювання ринку праці є розвиток програм професійної орієнтації молоді відповідно до його потреб, створення для випускників закладів вищої освіти рівного доступу до галузевих і професійних ринків праці, допомога у підборі робочого місця. Традиційно необхідним для України $\epsilon$ удосконалення державного і договірного регулювання оплати праці з метою підвищення їі розміру до європейських стандартів, у т.ч. формування рівня мінімальної заробітної плати відповідно до реальних можливостей задоволення потреб для повноцінного відтворення населення, посилення диференціації розміру заробітку залежно від професійно-кваліфікаційний характеристик працівника та зниження ставок оподаткування. Опосередкованими важелями 
регулювання ринку праці за рахунок забезпечення додатного міграційного сальдо на сьогодні вбачаємо спрощення доступу громадян до регіональних ринків житла, у т.ч. шляхом іпотечного кредитування та надання реемігрантам дозволів на відкриття власних валютних рахунків із встановленням на них вищих відсотків з метою подальшого придбання житла або ж започаткування власного бізнесу.

1. Бандур С.І. Розвиток соціально-трудових відносин як передумова досягнення продуктивної зайнятості населення. Ринок праці та зайнятість населення. 2014. № 1. С. 8-13. 2. Грішнова О.А. Економіка праці та соціально-трудові відносини : підручник. Київ : Знання, 2011. 390 с. 3. Колот А. М. Трансформация института занятости как составляющая глобальных изменений в социально-трудовой сфере: феномен прекаризации. Ринок праці та зайнятість населення. 2014. № 3. С. 10-13. 4. Лисюк О.С. Безробіття як соціально-економічна проблема населення України. Збірник наукових праць ВНАУ. 2012. № 4 (70). С. 48-53. 5. Лібанова Е. М. Ринок праці : навч. посіб. Київ : Центр навч. л-ри, 2003. 224 с. 6. Лісогор Л. С. Прогнозування розвитку ринку праці в Україні: проблеми та перспективи. Ринок праці та зайнятість населення. 2012. № 1. С. 54-56. 7. Юрчик І. Б. Взаємозв'язок ефективності ринку праці та його інституційного забезпечення. Науковий Вісник Херсонського державного університету. Економічні науки. 2016. № 17. Ч. 4. С. 109. 8. Брензович К. С., Глодан М. П. Аналіз міграційних потоків молоді України. Науковий вісник Ужгородського національного університету. Сер. Міжнародні економічні відносини та світове господарство / голов. ред. М. М. Палінчак. Ужгород : Гельветика, 2017. Вип. 16. Ч. 1. С. 26-29. 9. Чорна В. О. Трудова міграція молоді як фактор руйнування трудового потенціалу України. Наукові праці Чорноморського державного університету імені Петра Могили комплексу «Києво-Могилянська академія». Сер. Соціологія. 2014. Вип. 222. Т. 234. С. 109-112. 10. Мельничук Д. П. Міграційні наміри студентської молоді та їх вплив на мотиваційну складову людського капіталу України. Демографія та соціальна економіка. 2009. № 1. С. 116-124. 11. Мобільність та міграційні настрої української молоді. URL: https://pon.org.ua/novyny/7240-moblnst-ta-mgracyn-nastroyi-ukrayinskoyi-

molod.html (дата звернення: 15.12.2020). 12. Аналітична записка «Україна 2020: демографічні та міграційні виміри безпеки». К. : УІПП, 2012. С. 11. 13. Економічна активність населення України 2018. Стат. збірник / Державна служба статистики України.

URL: http://www.ukrstat.gov.ua/druk/publicat/kat_u/2019/zb/07/zb_EAN_2018.pdf (дата звернення: 15.12.2020). 14. Населення України за 2019 рік. Демографічний щорічник/Державна служба статистики України, 2020. URL: http://www.ukrstat.gov.ua/druk/publicat/kat_u/2020/zb/10/zb_nas_2019.pdf (дата звернення: 15.12.2020). 15. Гоць А. А. Міжнародна трудова міграція українців в умовах воєнного конфлікту на сході країни. Сучасні тенденції трудової міграції в Україні : прес-дайджест. II кв. 2019 р. / КЗ «ЗОУНБ» ЗОР, Від. наук. інформації та бібліографії ; підгот. Ю. Щеглова, ред. Т. Пішванова. Запоріжжя : ЗОУНБ, 2019. 24 с. 16. Праця України у 2018 році. Статистичний збірник / Державна служба статистики України, 2019.

URL: http://www.ukrstat.gov.ua/druk/publicat/kat_u/2019/zb/08/zb_pu2018_pdf. (дата звернення: 15.12.2020). 
Серія «Економічні науки»

Випуск 4(92) 2020 p.

\section{REFERENCES:}

1. Bandur S. I. Rozvytok sotsialno-trudovykh vidnosyn yak peredumova dosiahnennia produktyvnoi zainiatosti naselennia. Rynok pratsi ta zainiatist naselennia. 2014. № 1. S. 8-13. 2. Hrishnova 0. A. Ekonomika pratsi ta sotsialno-trudovi vidnosyny pidruchnyk. Kyiv : Znannia, 2011. 390 s. 3. Kolot A. M. Transformatsiya instituta zanyatosti kak sostavlyayuschaya globalnyih izmeneniy $\mathrm{v}$ sotsialno-trudovoy sfere: fenomen prekarizatsii. Rynok pratsi ta zainiatist naselennia. 2014. № 3. S. 10-13. 4. Lysiuk 0. S. Bezrobittia yak sotsialno-ekonomichna problema naselennia Ukrainy. Zbirnyk naukovykh prats VNAU. 2012. № 4 (70). S. 48-53. 5. Libanova E. M. Rynok pratsi : navch. posib. Kyiv : Tsentr navch. l-ry, 2003. 224 s. 6. Lisohor L. S. Prohnozuvannia rozvytku rynku pratsi v Ukraini: problemy ta perspektyvy. Rynok pratsi ta zainiatist naselennia. 2012. № 1. S. 54-56. 7. Yurchyk I. B. Vzaiemozviazok efektyvnosti rynku pratsi ta yoho instytutsiinoho zabezpechennia. Naukovyi Visnyk Khersonskoho derzhavnoho universytetu. Ekonomichni nauky. 2016. № 17. Ch. 4. S. 109. 8. Brenzovych K. S., Hlodan M. P. Analiz mihratsiinykh potokiv molodi Ukrainy. Naukovyi visnyk Uzhhorodskoho natsionalnoho universytetu. Ser. Mizhnarodni ekonomichni vidnosyny ta svitove hospodarstvo / holov. red. M. M. Palinchak. Uzhhorod : Helvetyka, 2017. Vyp. 16. Ch. 1. S. 26-29. 9. Chorna V. 0. Trudova mihratsiia molodi yak faktor ruinuvannia trudovoho potentsialu Ukrainy. Naukovi pratsi Chornomorskoho derzhavnoho universytetu imeni Petra Mohyly kompleksu «Kyievo-Mohylianska akademiia». Ser. Sotsiolohiia. 2014. Vyp. 222. T. 234. S. 109-112. 10. Melnychuk D. P. Mihratsiini namiry studentskoi molodi ta yikh vplyv na motyvatsiinu skladovu liudskoho kapitalu Ukrainy. Demohrafiia ta sotsialna ekonomika. 2009. № 1. S. 116-124. 11. Mobilnist ta mihratsiini nastroi ukrainskoi molodi. URL: https://pon.org.ua/novyny/7240-moblnstta-mgracyn-nastroyi-ukrayinskoyi-molod.html (data zvernennia: 15.12.2020). 12. Analitychna zapyska «Ukraina 2020: demohrafichni ta mihratsiini vymiry bezpeky». K. : UIPP, 2012. S. 11. 13. Ekonomichna aktyvnist naselennia Ukrainy 2018. Stat. zbirnyk / Derzhavna sluzhba statystyky Ukrainy. URL: http://www.ukrstat.gov.ua/druk/publicat/kat_u/2019/zb/07/zb_EAN_2018.pdf (data zvernennia: 15.12.2020). 14. Naselennia Ukrainy za 2019 rik. Demohrafichnyi shchorichnyk / Derzhavna sluzhba statystyky Ukrainy, 2020. URL: http://www.ukrstat.gov.ua/druk/publicat/kat_u/2020/zb/10/zb_nas_2019.pdf (data zvernennia: 15.12.2020). 15. Hots A. A. Mizhnarodna trudova mihratsiia ukraintsiv v umovakh voiennoho konfliktu na skhodi krainy. Suchasni tendentsii trudovoi mihratsii v Ukraini : pres-daidzhest. II kv. 2019 r. / KZ «ZOUNB»ZOR, Vid. nauk. informatsii ta bibliohrafii ; pidhot. Yu. Shchehlova, red. T. Pishvanova. Zaporizhzhia : ZOUNB, 2019. 24 s. 16. Pratsia Ukrainy u 2018 rotsi. Statystychnyi zbirnyk / Derzhavna sluzhba statystyky Ukrainy, $2019 . \quad$ URL: http://www.ukrstat.gov.ua/druk/publicat/kat_u/2019/zb/08/zb_pu2018_pdf. (data zvernennia: 15.12.2020). 
Kovshun N. E. [1; ORCID ID: 0000-0003-0573-2932],

Doctor of Economics, Professor

Mazur N. O. [1; ORCID ID: 0000-0001-8673-5873] Candidate of Economics (Ph.D.), Associate Professor

${ }^{1}$ National University of Water and Environmental Engineering, Rivne

\section{INFLUENCE OF YOUTH MIGRATION ON THE FORMATION OF THE PRIORITIES OF REGULATION OF THE LABOR MARKET OF UKRAINE}

At the present stage of our country development, complicated by economic and political crisis, it is important to optimize the basic parameters of the national labour market. Particular attention must be paid to the needs of the youth segment, due to emigration educated, skilled youth from Ukraine. The largest outflow of population abroad comes from the western regions of the country. This necessitates constant monitoring of the migration intentions of student youth and identifying the level of propensity to emigrate, as well as the causes and factors that forming migration mood. The purpose of the article is to analyse the migration mood of the youth of Rivne region, which will form recommendations for the formation of priorities for the regulation of the national labour market.

Migration processes in the youth segment of the labour market of Ukraine are studied. Peculiarities of youth migration of Rivne region as a region with a high level of labour outflow are considered. The results of questionnaires of 1-3 courses students of higher education institutions of Rivne region about their migration moods are presented. The level of interest of young people in going abroad for employment is established. Factors that stimulate migration processes are identified.

The results of the survey showed that $66 \%$ of respondents are not sure whether to go abroad or continue to live at home. $22 \%$ of respondents said that they would definitely stay to live in Ukraine. $12 \%$ of students are unequivocally focused on going abroad. The reasons for the migration mood of the youth of Rivne region are mainly economic factors. The main reason for migration is the lack of a job that would meet the personal requirements of young people (76\% of respondents). Students also want to leave Ukraine due to the lack of proper employment conditions (49\%), the inability to ensure a decent level of material well-being $(52 \%)$, and a high level of corruption (47\%). Less important is the desire to acquire new knowledge and skills $(31 \%)$.

The influence of the level of employment and of the level wages on the outflow of the population of Ukraine abroad is studied. Comparative analysis of statistical data of regions of Ukraine confirms the highest dependence of the outflow of population from the territories of the territorialadministrative units on the level of employment and income.

Keywords: unemployment; employment; wage; youth; migration; labour market; labour migration. 
Ковшун Н. Э. [1; ORCID ID: 0000-0003-0573-2932], д.э.Н., профессор Мазур H. A. [1; ORCID ID: 0000-0001-8673-5873], к.э.н., доцент

${ }^{1}$ Национальный университет водного хозяйства и природопользования, г. Ровно

\section{ВЛИЯНИЕ МОЛОДЕЖНОЙ МИГРАЦИИ НА ФОРМИРОВАНИЕ ПРИОРИТЕТОВ РЕГУЛИРОВАНИЯ РЫНКА ТРУДА УКРАИНЫ}

Исследованы миграционные процессы в молодежном сегменте рынка труда Украины. Рассмотрены особенности миграции молодежи Ровенской области, как региона с высоким уровнем оттока рабочей силы. Приведены результаты анкетирования студентов 1-3 курсов учреждений высшего образования Ровенщины с целью изучения их миграционных настроений. Установлен уровень заинтересованности молодежи в выезде за границу с целью трудоустройства. Определены факторы, стимулирующие миграционные процессы. Исследовано влияние уровня занятости и заработной платы на отток населения Украины за границу.

Ключевые слова: безработица; занятость; заработная плата; молодежь; миграция; рынок труда; трудовая миграция.

Стаття надійшла до редакції 17.12.2020 р. 